\title{
MAP1LC3C Gene
}

National Cancer Institute

\section{Source}

National Cancer Institute. MAP1LC3C Gene. NCI Thesaurus. Code C116661.

This gene plays a role in the formation of autophagosomes. 